\title{
BAUKO JÁNOS: Társadalom és névhasználat. Magyar névtani kutatások
}

Szlovákiában. Budapest, Magyar Nyelvtudományi Társaság, 2019. (228 lap)

Bauko János, a határon túli magyar névtudomány kiemelkedő alakja, tevékenységével fontos szerepet vállal a határon túli magyar névhasználat sajátosságainak feltárásában. Legújabb munkájának köszönhetően - mely a Magyar Névtani Értekezések 8. köteteként jelent meg — betekintést nyerhetünk a szlovákiai magyar vonatkozású névtani kutatásokba, a szlovákiai magyarok névhasználatába, a tulajdonnevek körében megjelenő magyar-szlovák kontaktusjelenségekbe. A tematikusan összefüggő tíz fejezet különböző szempont alapján tárgyalja a társadalom és a tulajdonnév-használat témakörét, a szlovákiai magyarok személynévnévhasználatát, a magyar-szlovák kétnyelvüség tulajdonnevekre gyakorolt hatását, valamint aktuális terminológiai kérdésekkel is foglalkozik.

Az első fejezetben a szerző kijelöli az onomasztika helyét a nyelvtudomány és a társtudományok rendszerében, valamint a társadalom és névhasználat összefüggéseivel foglalkozó szocioonomasztika kutatási területeit tekinti át. E szemle során kitér a névpolitika és a névtervezés, a névdivat és a névattitüd, a névkontaktológia és a kisebbségi névhasználat számtalan aspektusára. Bauko ezen kérdéskörök tárgyalására a későbbi fejezetekben is vissza-visszatér, s így kellő alapossággal mutatja be azokat.

A következő fejezet a szlovákiai (a szlovák és a szlovákiai magyar) onomasztikai kutatások történetét tárgyalja. Hangsúlyozza az intézményi háttér a Szlovák Tudományos Akadémián belül müködő Szlovák Névtudományi Bizottság — jelentőségét, mely fontos szerepet tölt be névtani konferenciák, tanácskozások, valamint monografikus jellegü névtani munkák körüli teendök koordinálásában.

Bauko János e fejezetben kitér a szlovákiai magyar névkutatás aktuális feladataira is. Hasznosnak tartaná a felvidéki témával foglalkozó névkutatók (elsősorban a szlovákiai illetékességüek) gyakoribb eszmecseréjét, tematikus tanácskozások megszervezését. Foglalkozik az onomasztika egyetemi képzésben való megjelenésével is, hangsúlyozva a névtudományi ismeretek tantárgyi kereteken belüli oktatásának létjogosultságát. „Fontosnak tartom az egyetemeken a »névtan/onomasztika« tantárgy oktatását, amelynek köszönhetően népszerüsíthetjük a névtudomány eredményeit [...], s a hallgatókat is bevonhatjuk a kutatói tevékenységbe" (49). A szerző ezen felvetésével teljes mértékben egyetérthetünk, mivel a nevek mint történelmünk és müvelődéstörténetünk becses tanúi, közösségünk múltjáról és jelenéről számtalan információt közvetítenek. Ezek ismerete 
kiemelten fontos a határon túli magyar közösségek identitástudatának megtartása, erősítése szempontjából.

A harmadik fejezet terminológiai kérdéseket érint. A vonatkozó szaknyelvi kutatások rövid áttekintését követően Bauko összehasonlítja a magyar és a szlovák (szláv) névtani terminológiát. A vizsgálat alapjául terminológiai szótárak és a témával kapcsolatos tanulmányok szolgáltak. Általános tapasztalatként azt szüri le, hogy: „míg a magyar névtani terminológiára a magyar terminusok használata (hungarocentrikusság), a csupán egyetlen nyelvben élő terminusok alkalmazása, addig a szlovák (szláv) névtani terminológiára az idegen terminusok használata (internacionalizmusra való törekvés), a több nyelvben is hasonló alakban és jelentésben élö terminusok alkalmazása jellemző" (61).

A többségi hatalom befolyásolhatja, korlátozhatja a kisebbségi nyelvü tulajdonnevek nyilvános használatát. Bauko ezzel a kérdéskörrel foglalkozik a negyedik fejezetben, amelyben a szlovákiai kisebbségi névpolitika jellemzőit, a hivatalos személynév-, helynév- és intézménynév-használatot befolyásoló névtörvényeket tárgyalja. Kitér a rendszerváltást követő, a nyelv- és névhasználatot korlátozó szabályozásokra, valamint az önálló Szlovákia megalakulása utáni fokozatos jogbővülésre.

A tulajdonnevek standardizálásának és az anyanyelvi névtervezés szlovákiai eredményeinek bemutatásával az ötödik fejezet foglalkozik. Ennek keretében külön tárgyalja a szerző a személy-, hely- és intézménynevek használatára vonatkozó standardizációs folyamatokat. Beszámol a készülő magyar-szlovák keresztnévszótárral kapcsolatos munkálatokról, mely befolyásolhatja az anyanyelvi névtervezés, illetve a szlovákiai magyarok személyneveinek anyanyelven történő anyakönyvezésének további alakulását.

A tulajdonnevek etnikai szimbólumként való müködéséröl, a tulajdonnév identitásjelölő funkciójáról a hatodik fejezetben olvashatunk. Az identitás fontos kifejezőjeként a nevek utalhatnak az egyén, illetve a közösség etnikai hovatartozására. Mindez hatványozottan igaz kétnyelvü környezetben, amelyre vonatkozóan Bauko megállapítja, hogy „A szlovákiai magyarokra a magyardomináns kétnyelvüség a jellemző, s ez a névhasználatban is megmutatkozik. Az élőnyelvben és az informális írott nyelvben az anyanyelvi (magyar) névalakok használata dominál, a hivatalos írásbeliségben azonban az államnyelv hatására megjelennek a nem anyanyelvi (szlovák) névformák is" (96).

Az egyes emberek, illetve kisebb-nagyobb közösségek nevekhez füződő viszonyát névattitüd-vizsgálatok révén tárhatjuk fel. A mindenkori névdivatot is nagyban befolyásolja a nevekhez való viszonyulás. Ennek okán a személynevekkel kapcsolatos attitüdvizsgálatok a névtudomány aktuális feladatai közé sorolhatók. Az egyes nevekhez való viszonyulást számtalan tényező befolyásolhatja. A lehetséges tényezőket a szerző - a nyitrai egyetemisták körében elvégzett — 
attitüdvizsgálat eredményeinek bemutatása révén veszi számba. A kutatás arra kereste a választ, hogy a hallgatók közül kinek és miért tetszik, illetve nem tetszik saját család- és keresztneve.

A szlovákiai keresztnévdivat változását, a magyar-szlovák kétnyelvü környezetben jelentkező névadási, névviselési, névhasználati sajátosságokat a hetedik fejezet tárgyalja. A keresztnév terminus használatának, illetve fogalmának tisztázása után Bauko sorra veszi a keresztnevek anyakönyvezésekor Szlovákiában és Magyarországon használatos névjegyzékeket, névkönyveket. Ezt követően a szlovákiai keresztnévdivat változásáról olvashatunk. A fiatalabb generációk neveiről az újszülötteknek1995-ben, 2000-ben és 2013-ban adott leggyakoribb nevek országos adatai alapján kapunk átfogó képet. A névdivat jelentősebb változását figyelhetjük meg az idősebb korosztályok, az 1953-ban és az 1983-ban születettek névstatisztikáinak bevonásával. Fontos adalékul, viszonyítási pontként szolgálnak a csehországi és a magyarországi névgyakorisági adatok is. A fejezet végén a magyar-szlovák kétnyelvü környezet keresztnévhasználatot befolyásoló tényezőit ismerhetjük meg.

A nyolcadik fejezetben a szlovákiai magyarok személynév-használatában előforduló kontaktusjelenségekről olvashatunk. A szlovákiai magyarok döntő többsége a kommunikációs helyzetnek megfelelően mindkét nyelvet képes használni, és ennek megfelelően ismeri a magyar és a szlovák tulajdonnévformákat is. Ennek ellenére a tulajdonnévi kódváltás nem ritka jelenség sem a szóbeli, sem az írott nyelvben. Bauko megállapítja, hogy a szlovákiai magyarokra jellemző a kettős személynévhasználat, mely az adott személy család- és keresztnevének magyar és szlovák alakváltozatainak használatát jelenti. E fejezetből azt is megtudhatjuk, hogy a szlovákiai magyarok becenév- és ragadványnév-használata viszont magyardominánsnak tekinthető. „Minél nagyobb százalékban lakják a települést magyarajkú lakosok, annál nagyobb mértékben találkoz(hat)unk a nem hivatalos személynevek körében magyar eredetü nevekkel" (136).

A kilencedik fejezet Szlovákia magyarlakta településeinek névszemiotikai tájképét, a vizuálisan megjelenő személy-, hely- és intézménynév-használatot vizsgálja. Egy adott terület nyelvi tájképét az útjelző és reklámtáblák, a különböző típusú helynevek, a kereskedelmi egységek és hivatalok, iskolák feliratai stb. alkotják. Kétnyelvü környezetben természetesen a két nyelv feliratai együttesen alakítják a nyelvi tájképet. A feliratokon megjelenő különböző névfajták vizsgálatával az adott terület névszemiotikai tájképe írható le. A kisebbségek számára mindenütt az otthonosságérzés fontos forrása, hogy nyelvük tulajdonnevei a vizuális térben is megjelenhessenek.

Bauko sorra veszi a névszemiotikai tájképet befolyásoló tényezőket, miközben külön figyelmet szentel a szlovákiai magyar beszélöközösség kétnyelvü környezetének. „A kétnyelvű névtáblák értelmezésében fontos a történelmi, politikai, 
szociokulturális összefüggések megértése, a látható, vizualizált kép létét meghatározó okozati háttér feltárása" (139) — állapítja meg. A fejezetben részletesen beszámol a személy-, hely- és intézménynevek feliratokon való megjelenéséről, a szlovákiai magyar települések névszemiotikai tájképének sajátosságairól.

A kiadvány utolsó, tizedik fejezete a magas-tátrai magyar-szlovák hegynévpárok elemzésével foglalkozik a kétnyelvüség és a fordítás tükrében. A hegynév fogalmának értelmezését és a hegyrajzi köznevek bemutatását követően a hegynevek kutatásáról olvashatunk rövid összefoglalót. Ezt követően a Magas-Tátra hegyneveinek magyar-szlovák névpárjait vizsgálja a szerző a tőle megszokott alapossággal. Megtudhatjuk, hogy a névpárok egy része azonos indíték alapján jött létre, ezek egymás fordításaiként értelmezhetők. Az eltérő indíték alapján keletkezett névpárok esetében fény derül a névadást motiváló tényezőkre is. A magyar elnevezések döntő többségükben személynévből származó tiszteleti nevek, míg a szlovák megnevezések különböző motivációk alapján keletkeztek.

A kiadványt háromnyelvü összefoglaló és gazdag irodalomjegyzék zárja.

A Társadalom és névhasználat címủ munka a magyar névtudomány gazdag hagyományait gyarapítja. Bauko János kötetét meleg szívvel ajánlom a névtan iránt érdeklődő olvasóknak és a szakmai közönségnek egyaránt.

TÖRÖK TAMÁS

ORCID: 0000-0002-3116-9875

Selye János Egyetem, Komárom torokt@ujs.sk 